\title{
Development of Highly-Active and Stable Pt/C catalyst for Polymer Electrolyte Membrane Fuel Cells under Simulated Start-up/Shut-down Cycling
}

Taekeun Kim and Branko N. Popov*

Center for Electrochemical Engineering, Department of Chemical Engineering, University of

South Carolina, Columbia, SC 29208

Submitted as a research paper to

E.A. Verziroglu

Editor-in-Chief, International Journal of Hydrogen Energy

November 2015

*Corresponding author

Branko N. Popov

Tel (803) 777-7314

Fax (803) 777-8265

Email: popov@,cec.sc.edu 


\begin{abstract}
Activated carbon composite support (ACCS) is synthesized using a novel methodology developed at University of South Carolina (USC). The ACCS shows good thermal stability similar to that of carbon nanofibers (CNFs). Pt/ACCS catalyst shows excellent support stability under simulated start-up/shut-down operating conditions (1.0-1.5 V, 5000 cycles). The Pt/ACCS shows a maximum power density of $722 \mathrm{~mW} \mathrm{~cm}^{-2}$ while commercial $\mathrm{Pt} / \mathrm{C}$ and $\mathrm{Pt} / 290 \mathrm{G}$ catalysts show 495 and $530 \mathrm{~mW} \mathrm{~cm}^{-2}$, respectively. Furthermore, Pt/ACCS shows no loss of mass activity and maximum power density after 5000 cycles at $1.0-1.5 \mathrm{~V}$. The commercial $\mathrm{Pt} / \mathrm{C}$ and $\mathrm{Pt} / 290 \mathrm{G}$ catalysts show drastic mass activity losses (57.5\% and 66.2\%, respectively) and maximum power density losses (88.7\% and $84.0 \%$, respectively). The good activity and excellent stability of Pt/ACCS catalyst are attributed to the higher degree of graphitization and enhanced hydrophobicity of ACCS. For the first time, we report a carbon-based support which is stable under simulated start-up/shut-down operating conditions.
\end{abstract}

Keywords: Polymer electrolyte membrane fuel cells; Pt/C cathode catalyst; support stability; start-up/shut-down cycling; carbon corrosion 


\section{Introduction}

With the limited fossil fuel reserve and increased power demand, polymer electrolyte membrane fuel cells (PEMFC) are considered to be an alternative to the current energy consumption mode due to its high energy conversion, zero emission, modularity, scalability, quick installation, and cogeneration operations [1, 2]. Pt and Pt-based alloy catalysts are most commonly used as cathode catalysts for PEMFCs due to their high activity and stability [3-5]. However, the high cost of Pt metal is an obstacle for the commercialization of PEMFCs for automotive applications [6]. To overcome the cost issues of Pt-based catalysts, many recent studies have focused on decreasing the Pt loadings and increasing the Pt utilization in fuel cell electrodes while maintaining the activity and stability [7].

The high surface area carbon (HSAC) is widely used as the catalyst support to improve $\mathrm{Pt}$ utilization because of its good electrical conductivity, pore structure suitable for Pt anchorage, high-surface-area for uniform Pt particle dispersion, easy availability, and low cost [8, 9]. However, many studies have shown that HSAC has low resistance towards thermal and electrochemical oxidation because of the HSAC structure containing mainly amorphous carbon and a small portion of plane graphite carbon, which has an abundance of dangling bonds and defects [10]. The dangling bonds can easily form surface oxides, which results in a higher corrosion rate under electrochemical oxidation. To improve the electrochemical stability of the carbon support and overall $\mathrm{Pt} / \mathrm{C}$ catalyst, new carbon materials have been tested as supports for PEMFC, including nano-diamonds [11-13], carbon nanotubes (CNT) [14-16], carbon nanofibers (CNF) $[15,17,18]$, carbon nanocages (CNC) [17, 19], graphene [20, 21], etc. These carbon materials have shown enhanced thermal and electrochemical stability due to higher degree of graphitization of carbon and inert surface structures toward carbon oxidation [14]. However, 
these properties also act as drawbacks in the preparation of $\mathrm{Pt} / \mathrm{C}$ catalysts since they do not provide proper active sites for Pt deposition. Furthermore, hydrophobic nature of their surfaces impedes dispersion in a polar solvent thus preventing the Pt deposition on the surfaces [18]. It may cause difficulty in controlling the particle size, uniform distribution of Pt particles, and achieving high metal loading, which results in low activity of catalysts [22]. In order to enhance Pt deposition on these carbons, a surface functionalization is required. However, it makes the catalyst preparation more complex and increases the cost. In addition, after attaching the functional groups on carbons, the surface properties are usually influenced, and the stability of functionalized material will be decreased as a result [18]. Relatively high cost of the alternative carbon supports is another obstacle besides the fact that the cost of these materials has fallen continuously in recent years [23].

To examine the electrochemical stability of carbon support material in PEMFC condition, various methods have been suggested [24]. Generally, it is required to operate more than $5000 \mathrm{~h}$ to apply PEMFCs to the automotive application [25]. However, it is impractical and inefficient to estimate the stability under practical conditions because of long testing time and cost. The U.S. Department of Energy (DOE), U.S. Fuel Cell Council (USFCC), and the Fuel Cell Commercialization Conference of Japan (FCCJ) proposed several effective accelerated stress test (AST) methods to test the stability of Pt-based catalysts [26-29]. A good AST method should satisfy several conditions: (i) relatively short testing time, (ii) good selectivity with regard to carbon degradation, and (iii) good degradation behavior of fuel cell performance [30]. To establish appropriate AST protocol to meet all the conditions mentioned above, it is important to understand the mechanism of carbon corrosion at various potential regions and potential profiles (constant potential, triangular cycling, rectangular cycling, etc). Reiser et al. suggested that a 
cathode interfacial potential difference would be increased up to $\sim 1.5 \mathrm{~V}$ due to the " $\mathrm{H}_{2} /$ air front" mechanism in the case of start-up/shut-down process [31]. The same phenomenon also occurs in the case of local hydrogen starvation in the MEA [32]. Furthermore, it has been shown that the cathode potential behavior follows a triangular change with the maximum potential of $\sim 1.5 \mathrm{~V}$ when $\mathrm{H}_{2}$ introduced to the anode compartment [29]. Recently, Hashimasa et al. studied the effects of the potential waveform on carbon corrosion rate by comparing $1.3 \mathrm{~V}$ constant potential with $0.9-1.3 \mathrm{~V}$ potential cycling [30]. If the carbon corrosion is only affected by high potential, holding the potential at high value would show high carbon corrosion rate. However, the carbon corrosion rate of $0.9-1.3 \mathrm{~V}$ potential cycling was higher than that of $1.3 \mathrm{~V}$ constant potential. Park et al. proposed the reason of this phenomenon that de-passivated Pt at the lower potential catalyzes carbon corrosion when potential is increased [33]. These results indicated that the potential cycling is more effective than potential holding to test carbon corrosion. But there is still an issue with regard to the lower potential limit of potential cycling; lower potentials than $0.9 \mathrm{~V}$ in the potential cycling would also result in Pt degradation through the Pt oxidation and reduction processes [34]. Therefore, the performance loss by carbon corrosion and the one by $\mathrm{Pt}$ degradation will be mixed resulting in the poor selectivity of carbon support degradation. Thus, the potential above $1.0 \mathrm{~V}$ at which $\mathrm{Pt}$ is passivated all the time should be used as the lower potential limit of a potential cycling test to study the carbon support stability without the contribution of Pt degradation. According to all these studies, the potential cycling between 1.0 and $1.5 \mathrm{~V}$ would be a good AST protocol to test the carbon support stability in PEMFC. Actually, the FCCJ suggested a potential cycling protocol $\left(1.0-1.5 \mathrm{~V}, 5000\right.$ cycles, $\left.500 \mathrm{mV} \mathrm{s}^{-1}\right)$ to test the support stability in 2011 [29], and the U.S. DOE substituted their previous protocol $(1.2 \mathrm{~V}$ constant potential for $400 \mathrm{~h})$ with the same protocol as the FCCJ in 2013 [35]. This 
protocol also reduces the testing time $\left(2 \mathrm{sec}\right.$ cycle $^{-1},<3 \mathrm{~h}$ total). Mukundan reported the comparison of the old protocol $(1.2 \mathrm{~V}$ constant potential for $400 \mathrm{~h})$ and the new protocol $(1.0-1.5$ $\mathrm{V}, 5000$ cycles, $500 \mathrm{mV} \mathrm{s}^{-1}$ ) of U.S. DOE [36]. It was observed that $200 \mathrm{~h}$ constant potential at $1.2 \mathrm{~V}$ is equivalent to 2000 cycles at $1.0-1.5 \mathrm{~V}$. According to the result, the author concluded that the new protocol could reduce the testing time significantly ( $\sim 100$ times) when compared to the old protocol with the same performance decay. Due to the advantages outlined above, in this study, the 1.0-1.5 $\mathrm{V}$ potential cycling protocol has been selected to test the carbon support stability for Pt catalysts deposited on various carbon materials.

The activated carbon composite support (ACCS) which was obtained from carbon black has ideal properties for Pt deposition similar to that of carbon blacks. In addition, the preliminary study of thermal stability showed that ACCS has good thermal stability similar to that of CNFs. From these advantages of ACCS, it was considered as a promising support material for Pt catalyst and was studied extensively for its electrochemical activity and stability in this study. The membrane electrode assembly (MEA) performance and support stability were studied with Pt loading of $0.1 \mathrm{mg} \mathrm{cm}^{-2}$ on both cathode and anode electrodes.

\section{Experimental}

\subsection{Synthesis of activated carbon composite support (ACCS)}

The ACCS was synthesized by two-step process - purification and stabilization - from a carbon black. The carbon black was heat treated at $350-600{ }^{\circ} \mathrm{C}$ for $1-3 \mathrm{~h}$ under pure oxygen or air flow to remove the electrochemically unstable amorphous carbon. Next, the sample was heat treated at $850-1200{ }^{\circ} \mathrm{C}$ for $0.5-2 \mathrm{~h}$ under $\mathrm{N}_{2}$ or Ar flow. With this step, oxygen functional groups could be removed from the carbon surface thus makes ACCS more corrosion resistant. The process of ACCS synthesis was also described in our previous publication [37]. 


\subsection{Carbon thermal stability and thermogravimetric analysis}

A variety of carbon supports such as Ketjenblack EC-300J (Akzo Nobel), Vulcan XC-72

(Cabot), Ensaco 290G (Timcal), ACCS (in-house), and CNF (Sigma-Aldrich) were selected and their thermal stability was measured by heat treatment at $600{ }^{\circ} \mathrm{C}$ for $1 \mathrm{~h}$ with $10{ }^{\circ} \mathrm{C} \min ^{-1}$ ramping time in a tube furnace with constant air flow $\left(150 \mathrm{ml} \mathrm{min}^{-1}\right)$. The weights before and after heat treatment were measured using a digital balance to calculate the weight loss of each carbon. Complete thermal decomposition of carbons was studied by thermogravimetric analysis (TGA) (Q5000IR, TA Instruments). The experiments were conducted under mixed gas of $10 \mathrm{ml}$ $\min ^{-1}$ of nitrogen and $25 \mathrm{ml} \mathrm{min}{ }^{-1}$ of air. The temperature was increased up to $1000{ }^{\circ} \mathrm{C}$ at $10{ }^{\circ} \mathrm{C}$ $\min ^{-1}$ ramping time.

\subsection{Synthesis of Pt/C catalyst}

Platinum nanoparticle deposition with an initial loading of $30 \mathrm{wt}$ \% Pt was carried out using a modified polyol process, which uses additives to control the particle size and to enhance the catalyst-support interaction. In brief, a measured amount of $\mathrm{PtCl}_{4}$ was dissolved in an appropriate volume of ethylene glycol under vigorous stirring for $30 \mathrm{~min}$. Calculated amount of carbon support was added to the solution so that the desired initial Pt loading was achieved in the final $\mathrm{Pt} / \mathrm{C}$ catalyst. Then, $0.5 \mathrm{M} \mathrm{NaOH}$ was introduced into the solution to adjust the $\mathrm{pH}$ in the range between 11 and 12 . The resulting suspension was stirred for $1 \mathrm{~h}$ at room temperature followed by refluxing at $160{ }^{\circ} \mathrm{C}$ for $3 \mathrm{~h}$. The solution was allowed to cool down to room temperature and kept for $12 \mathrm{~h}$ under continuous stirring. $0.1 \mathrm{M} \mathrm{H}_{2} \mathrm{SO}_{4}$ was then added to the cooled mixture and the solution $\mathrm{pH}$ was adjusted to 3 . The mixture was kept under stirring for 24 h. The catalyst in the solution was filtered and thoroughly washed with de-ionized water. The resulting Pt/C catalyst was dried at $160{ }^{\circ} \mathrm{C}$ and stored for further studies. 


\subsection{Material characterization studies}

The physical properties of carbon supports and $\mathrm{Pt} / \mathrm{C}$ catalysts were studied using $\mathrm{X}$-ray diffraction (XRD), Brunauer-Emmett-Teller (BET) surface area analysis, and high-resolution transmission electron microscopy (HRTEM). XRD patterns were recorded using Rigaku 405S5 to identify the crystalline structure of the synthesized supports and catalysts. BET (Quantachrome) was used to determine the surface area and pore-size distribution of the carbons. HRTEM (Hitachi H9500) was used to determine the Pt particle size of Pt/C catalysts.

\subsection{Fuel Cell Performance and Stability Studies}

The polarization performances of commercial Pt/C (TEC10E30E, 28.2 wt. \% Pt on Ketjenblack EC-300J, Tanaka Kikinzoku Kogyo K.K., Japan), in-house synthesized 30 wt. \% Pt/290G (Pt deposited on Ensaco 290G), and in-house synthesized 30 wt. \% Pt/ACCS catalysts were evaluated in $25 \mathrm{~cm}^{2}$ MEAs. The commercial Pt/C catalyst (TEC10E50E, $46.7 \mathrm{wt}$ \% Pt on Ketjenblack-EC300J, Tanaka Kikinzoku Kogyo K.K., Japan) was used as the anode catalyst in all the MEAs. The catalyst inks for the anode and cathode were prepared by blending the catalysts in de-ionized water, isopropyl alcohol, and 5\% solution of Nafion ${ }^{\circledR}$ in isopropyl alcohol (Alfa Aesar) in an ultrasonic bath. The catalyst inks were directly deposited onto the Nafion ${ }^{\circledR}$ NRE 212 membrane using a spray gun. The anode and cathode catalyst loading was fixed at 0.1 $\mathrm{mg}_{\mathrm{Pt}} \mathrm{cm}^{-2}$ and confirmed using XRF. Commercially available carbon paper (SGL $10 \mathrm{BC}$ ) was used as the gas diffusion layer (GDL) for both anode and cathode. The catalyst coated membranes were hot-pressed with GDLs at $140{ }^{\circ} \mathrm{C}$ for 3 min. under $14 \mathrm{~kg} \mathrm{~cm}^{-2}$ to form MEAs. Initially, the MEA was activated under a supply of $\mathrm{H}_{2}$ and $\mathrm{O}_{2}$ at $80{ }^{\circ} \mathrm{C}$ to the anode and cathode compartments, respectively, and the initial polarization performance curves were recorded with a flow rate of $750 \mathrm{ml} \mathrm{min}{ }^{-1}$ and $100 \% \mathrm{RH}$. The catalyst mass activity was evaluated under $\mathrm{H}_{2} / \mathrm{O}_{2}$ 
(2/9.5 stoic.) at $80{ }^{\circ} \mathrm{C}, 100 \% \mathrm{RH}$, and $150 \mathrm{kPa}_{\text {abs }}$ back pressure. The polarization curves were recorded under $\mathrm{H}_{2} /$ air $\left(2 / 2\right.$ stoic.) at $80{ }^{\circ} \mathrm{C}, 40 \% \mathrm{RH}$, and $170 \mathrm{kPa}_{\mathrm{abs}}$ back pressure. Electrochemical impedance spectroscopy (EIS) measurements were conducted in the frequency range from 0.025 to $1000 \mathrm{~Hz}$ at $10 \mathrm{~mA} \mathrm{~cm}^{-1}$ polarized condition using the in-built EIS analyzer in the Fuel Cell Test System (Model 850e, Scribner Associates, USA) under $\mathrm{H}_{2} /$ air (2/2 stoic.) at $80{ }^{\circ} \mathrm{C}, 40 \% \mathrm{RH}$, and $170 \mathrm{kPa}_{\mathrm{abs}}$ back pressure.

The support stability was evaluated using a simulated start-up/shut-down cycling experiment. The experiment was performed by cycling between 1.0 and $1.5 \mathrm{~V}$ for 5000 cycles with $500 \mathrm{mV} \mathrm{s}^{-1}$ scan rate at a cell temperature of $80{ }^{\circ} \mathrm{C}$ [35]. During the experiment, pure hydrogen $\left(200 \mathrm{cc} \mathrm{min}{ }^{-1}\right)$ and nitrogen $\left(75 \mathrm{cc} \mathrm{min}^{-1}\right)$ having $100 \% \mathrm{RH}$ were supplied to the anode and cathode compartments, respectively. The mass activity loss under $\mathrm{H}_{2} / \mathrm{O}_{2}$ and the maximum power density loss under $\mathrm{H}_{2} /$ air after 5000 potential cycles were used to evaluate the support stability.

\section{Results and discussions}

\subsection{Carbon supports characterization}

The thermal stability of various carbons was examined by heat treatment under air flow at $600{ }^{\circ} \mathrm{C}$ for $1 \mathrm{~h}$. Fig. 1 shows the weight retentions after thermal stability test for various carbons. The Ketjenblack EC-300J, Vulcan XC-72, Ensaco 290G, CNF, and ACCS developed at University of South Carolina (USC) were compared. While two commonly used carbon supports such as Ketjenblack EC-300J and Vulcan XC-72 show low weight retention after thermal stability test (1.0\% for Ketjenblack EC-300J and $13.4 \%$ for Vulcan XC-72), ACCS shows $90.7 \%$ retention which is similar to that of CNF (91.4\%). The thermal stability results indicate that ACCS is more stable than Ketjenblack EC-300J and Vulcan XC-72 carbons. S.M. Andersen et 
al. [22] claimed that CNF and CNT supports for Pt cathode catalyst showed higher thermal stability as well as higher electrochemical stability in MEA test $(0-1.6 \mathrm{~V}, 15000$ cycling $)$ than those of carbon black support. From the thermal stability test results, it is expected that the ACCS which showed similar thermal stability as the CNF would show good electrochemical stability in MEA tests.

Among various carbons, Ketjenblack EC-300J, Ensaco 290G and ACCS were selected for more detailed thermal decomposition analysis using TGA. Fig. 2 shows the result of TGA for the three selected carbons. The ACCS shows the highest thermal stability by showing highest onset temperature for decomposition. The Ensaco 290G shows intermediate thermal stability and Ketjenblack EC-300J shows the lowest thermal stability which agrees well with the thermal stability study results presented in Fig. 1. The temperatures at a maximum derivation of weight loss are 705,740 , and $781{ }^{\circ} \mathrm{C}$ for Ketjenblack EC-300J, Ensaco 290G, and ACCS, respectively.

The XRD patterns of Ketjenblack EC-300J, Ensaco 290G and ACCS are shown in Fig. 3. The crystallite thickness $\left(\mathrm{L}_{\mathrm{c}}\right)$ calculated by Scherrer's formula and the interlayer spacing $\left(\mathrm{d}_{002}\right)$ obtained from Bragg's law are used as the factors to determine the degree of graphitization of carbons. It has been reported that higher $\mathrm{L}_{\mathrm{c}}$ value of the (002) peak and lower $\mathrm{d}_{002}$ number imply a higher degree of graphitization $[17,38,39]$. The ACCS shows $L_{c}$ value which is almost twice higher than that of Ketjenblack EC-300J and Enasco 290G, and the lowest $\mathrm{d}_{002}$ of 0.349 when compared to the other two carbons. From the XRD analysis, a higher degree of graphitization of ACCS compared with the Ketjenblack EC-300J and Ensaco 290G was observed and it could be attributed to the higher thermal stability of ACCS than Ketjenblack EC-300J and Ensaco 290G. The BET surface area, maximum derivation of weight loss on TGA, $\mathrm{L}_{\mathrm{c}}$ values, and $\mathrm{d}_{002}$ values obtained from XRD analysis are summarized in Table 1. 


\subsection{Pt deposition}

The 30 wt. \% Pt on Ensaco 290G carbon support (Pt/290G) and 30 wt. \% Pt on ACCS support (Pt/ACCS) catalysts were synthesized using a modified polyol reduction process described in section 2.3. Commercially available Pt/C (TEC10E30E, 28.2\% Pt on Ketjenblack EC-300J) was compared with Pt/290G and Pt/ACCS as a cathode catalyst to represent the Pt catalyst on Ketjenblack EC-300J support since Ketjenblack-EC300J was used as a support material for this commercial catalyst [40]. The XRD patterns of commercial $\mathrm{Pt} / \mathrm{C}, \mathrm{Pt} / 290 \mathrm{G}$, and Pt/ACCS catalysts are compared in Fig. 4. The diffraction patterns represent all the reflections corresponding to the face centered cubic (fcc) lattice of Pt supported on various carbon supports. Scherrer's equation was used for calculating the Pt crystallite size using the Pt(220) peak appearing at $67.5^{\circ}[41,42]$. The $\mathrm{d}_{\mathrm{Pt}}$ values calculated from the XRD analysis are $1.6,3.2$, and 2.1 $\mathrm{nm}$ for the commercial Pt/C, Pt/290G, and Pt/ACCS catalysts, respectively, which are confirmed by the HRTEM images and corresponding particle size distribution shown in Fig. 5.

\subsection{MEA performance evaluation and support stability test under 1.0-1.5 V cycling}

The support stability tests were carried out by subjecting the MEAs to a potential cycling test $(1.0-1.5 \mathrm{~V}, 5000$ cycles) to simulate the start-up/shut-down conditions of an automotive PEMFC. The corrosion rate of carbon increases drastically at high electrode potentials, and can result in severe degradation of the carbon support via the following reaction [43]:

$$
\mathrm{C}+2 \mathrm{H}_{2} \mathrm{O} \rightarrow \mathrm{CO}_{2}+4 \mathrm{H}^{+}+4 \mathrm{e}^{-} \quad \mathrm{E}^{\circ}=0.207 \mathrm{~V} \text { vs. } \mathrm{RHE}
$$

Oxidation of the carbon surface increases its hydrophilicity and affects water removal, resulting in an increased mass-transfer resistance. In addition, oxidation of carbon increases the electrical resistance of the catalysts [44, 45], which leads to the detachment or aggregation of 
catalyst particles, and damages the cathode catalyst layer structure. Furthermore, platinum increases the corrosion rate by catalyzing the carbon oxidation [22].

Fig. 6 shows $\mathrm{H}_{2}$-air fuel cell polarization curves for the three different cathode catalysts. After 5000 cycles, the Pt/ACCS shows no loss in $\mathrm{H}_{2}$-air performance indicating good support stability under high potentials (Fig. 6(c)). On the other hand, commercial Pt/C catalyst shows $69.5 \%$ power density loss only after 1000 cycles and a further decrease to $88.7 \%$ after 5000 cycles (Fig. 6(a)). The Pt/290G catalyst shows moderate stability with $22.5 \%$ power density loss until 2000 cycles and a rapid decay between 2000 and 5000 cycles resulting in overall power density loss of $84.0 \%$ (Fig. 6(b)). Mass activities under $\mathrm{H}_{2}-\mathrm{O}_{2}$ operating conditions at $0.9 \mathrm{~V}_{\text {iR-corr }}$ were measured before and after support stability test to examine the kinetic performance changes of these three catalysts (Fig. 7). The Pt/ACCS catalyst shows no loss after the support stability test while commercial $\mathrm{Pt} / \mathrm{C}$ and $\mathrm{Pt} / 290 \mathrm{G}$ catalysts show $57.5 \%$ and $66.2 \%$ losses, respectively. Similar trends were observed in EIS analysis (Fig. 8). Commercial Pt/C and Pt/290G catalysts show an increase of charge-transfer resistance after the support stability test, but Pt/ACCS shows a small decrease of resistance. The maximum power densities and mass activities before and after the stability test for commercial Pt/C, Pt/290G, and Pt/ACCS catalysts are summarized in Table 2.

The good support stability of ACCS was attributed to the higher degree of graphitization of ACCS than Ketjenblack EC-300J and Ensaco 290G supports which was confirmed by XRD analysis. Also, it could be elucidated by the hydrophobic character of ACCS since carbon corrosion occurs in the presence of water [46]. In order to determine the hydrophilic/hydrophobic nature, the carbon supports were dispersed in water/hexane mixture and the results are shown in Fig. 9. The Ketjenblack EC-300J and Ensaco 290G carbon supports are mainly dispersed in the 
water phase which indicates the hydrophilicity of these carbons. On the other hand, ACCS shows dispersion mainly in the hexane phase while only a small amount of carbon is dispersed in the water phase which shows good hydrophobic property for ACCS when compared with the other two carbons. The enhanced hydrophobic property of ACCS is also confirmed by the contact angle measurement. As shown in Fig. 10, ACCS showed a contact angle of $132^{\circ}$ which is substantially greater than that for Ketjenblack EC-300J (38 $)$ and Ensaco 290G $\left(32^{\circ}\right)$ carbons. The enhanced hydrophobic property of ACCS can minimize water adsorption on the carbon surface resulting in less carbon corrosion. Furthermore, the difference in hydrophobicity affects the $\mathrm{H}_{2}$-air fuel cell performance in the mass-transport region. While commercial $\mathrm{Pt} / \mathrm{C}$ and $\mathrm{Pt} / 290 \mathrm{G}$ show current densities of $950 \mathrm{~mA} \mathrm{~cm}^{-2}$ and $1250 \mathrm{~mA} \mathrm{~cm}^{-2}$ at $0.6 \mathrm{~V}_{\mathrm{iR} \text {-corr }}$, respectively,

Pt/ACCS shows $1700 \mathrm{~mA} \mathrm{~cm}{ }^{-2}$ at $0.6 \mathrm{~V}_{\mathrm{iR} \text {-corr }}$. The higher $\mathrm{H}_{2}$-air fuel cell performance of Pt/ACCS is due to: (i) optimized support properties such as BET surface area which resulted in thin catalyst layer thus favoring effective mass-transfer to the Pt catalytic sites and (ii) hydrophobicity of the ACCS support which results in better water removal during high current operation.

\section{Conclusion}

The ACCS obtained from USC novel methodology was employed as a support material for Pt/C cathode catalyst to improve the catalytic activity and stability under PEMFC operating conditions. Pyrolysis at $600{ }^{\circ} \mathrm{C}$ result showed good thermal stability of ACCS which is similar to that of CNFs. Also, complete decomposition study by TGA confirmed the good thermal stability of ACCS. Potential cycling between 1.0 and $1.5 \mathrm{~V}$ for 5000 cycles showed no loss in $\mathrm{H}_{2}$-air fuel cell performance and mass activity for the Pt/ACCS catalyst while commercial Pt/C and Pt/290G showed drastic performance losses after the stability test. The good stability of ACCS at high 
potentials is attributed to the higher degree of graphitization which was confirmed by XRD analysis and enhanced hydrophobic property of ACCS when compared to Ketjenblack EC-300J and Ensaco 290G carbons. 


\section{Acknowledgement}

The financial support of U.S. Department of Energy (contract no. DE-EE0000460) is gratefully acknowledged. 


\section{References}

1. Xu H, Kong L, Wen X. Fuel cell power system and high power DC-DC converter. IEEE T Power Electr 2004; 19: 1250-5.

2. Kirubakaran A, Jain S, Nema RK. A review on fuel cell technologies and power electronic interface. Renew Sust Enegr Rev 2009; 13: 2430-40.

3. Popov BN, Li X, Liu G, Lee JW. Power source research at USC: Development of advanced electrocatalysts for polymer electrolyte membrane fuel cells. Int J Hydrogen Energ 2011; 36: 1794-802.

4. Li X, Park S, Popov BN. Highly stable Pt and PtPd hybrid catalysts supported on a nitrogen-modified carbon composite for fuel cell application. J Power Sources 2010; 195: $445-52$.

5. Liu G, Li X, Lee JW, Popov BN. A review of the development of nitrogen-modified carbon-based catalysts for oxygen reduction at USC. Catal Sci Tech 2011; 1: 207-17.

6. Zhang S, Xiaozi Y, Wang H, Merida W, Zhu H, Shen J, Wu S, Zhang J. A review of accelerated stress tests of MEA durability in PEM fuel cells. Int J Hydrogen Energ 2009; 34: 388-404.

7. Yu X, Ye S, Recent advances in activity and durability enhancement of Pt/C catalytic cathode in PEMFC: Part I. Physico-chemical and electronic interaction between Pt and carbon support, and activity enhancement of Pt/C catalyst. J Power Sources 2007; 172: $133-44$.

8. Kim M, Park J, Kim H, Song S, Lee W. The preparation of Pt/C catalysts using various carbon materials for the cathode of PEMFC. J Power Sources 2006; 163: 93-7.

9. Dicks AL. The role of carbon in fuel cells. J Power Sources 2006; 156: 128-41. 
10. Shao Y, Yin G, Zhang J, Gao Y. Comparative investigation of the resistance to electrochemical oxidation of carbon black and carbon nanotubes in aqueous sulfuric acid solution. Electrochim Acta 2006; 51: 5853-7.

11. Honda K, Yoshimura M, Rao TN, Tryk DA, Fujishima A, Yasui K, Sakamoto Y, Nishio K, Masuda H. Electrochemical properties of Pt-modified nano-honeycomb diamond electrodes. J Electroanal Chem 2001; 514: 35-50.

12. Montilla F, Morallon E, Duo I, Comninellis Ch, Vazquez JL. Platinum particles deposited on synthetic boron-doped diamond surfaces. Application to methanol oxidation. Electrochim Acta 2003; 48: 3891-7.

13. Spătaru N, Zhang X, Spătaru T, Tryk DA, Fujishima A. Platinum electrodeposition on conductive diamond powder and its application to methanol oxidation in acidic media. $\mathrm{J}$ Electrochem Soc 2008; 155: B264-9.

14. Han KI, Lee JS, Park SO, Lee SW, Park YW, Kim H. Studies on the anode catalysts of carbon nanotube for DMFC. Electrochim Acta 2004; 50: 791-4.

15. Lee K, Zhang J, Wang H, Wilkinson DP. Progress in the synthesis of carbon nanotubeand nanofiber-supported Pt electrocatalysts for PEM fuel cell catalysis. J Appl Electrochem 2006; 36: 507-22.

16. Wang C, Waje M, Wang X, Tang JM, Haddon RC, Yan Y. Proton exchange membrane fuel cells with carbon nanotube based electrodes. Nano Lett 2004; 4: 345-8.

17. Oh HS, Lim KH, Roh B, Hwang I, Kim H. Corrosion resistance and sintering effect of carbon supports in polymer electrolyte membrane fuel cells. Electrochim Acta 2009; 54: 6515-21. 
18. Oh HS, Kim K, Ko YJ, Kim H. Effect of chemical oxidation of CNFs on the electrochemical carbon corrosion in polymer electrolyte membrane fuel cells. Int $\mathrm{J}$ Hydrogen Energ 2010; 35: 701-8.

19. Lim KH, Oh HS, Kim H. Use of a carbon nanocage as a catalyst support in polymer electrolyte membrane fuel cells. Electrochem Commun 2009; 11: 1131-4.

20. Rao CV, Reddy ALM, Ishikawa Y, Ajayan PM. Synthesis and electrocatalytic oxygen reduction activity of graphene-supported $\mathrm{Pt}_{3} \mathrm{Co}$ and $\mathrm{Pt}_{3} \mathrm{Cr}$ alloy nanoparticles. Carbon 2011; 49: 931-6.

21. Shao Y, Zhang S, Wang C, Nie Z, Liu J, Wang Y, Lin Y. Highly durable graphene nanoplatelets supported Pt nanocatalysts for oxygen reduction. J Power Sources 2010; 195: 4600-5.

22. Anderson SM, Borghei M, Lund P, Elina Y, Pasanen A, Kauppinen E, Ruiz V, Kauranen P, Skou EM. Durability of carbon nanofiber (CNF) \& carbon nanotube (CNT) as catalyst support for Proton Exchange Membrane Fuel Cells. Solid State Ionics 2013; 231: 94-101.

23. Ma PC, Liu MY, Zhang H, Wang SQ, Wang R, Wang K, Wong YK, Tang BZ, Hong SH, Paik KW, Kim JK. Enhanced electrical conductivity of nanocomposites containing hybrid fillers of carbon nanotubes and carbon black. ACS Appl Mater Interfaces 2009; 1: 1090-6.

24. Antolini E. Carbon supports for low-temperature fuel cell catalysts. Appl Catal BEnviron 2009; 88: 1-24.

25. Knights SD, Colbow KM, St-Pierre J, Wilkinson DP. Aging mechanisms and lifetime of PEFC and DMFC. J Power Sources 2004; 127: 127-34. 
26. DOE cell component accelerated stress test protocols for PEM fuel cells. March 2007. http://www1.eere.energy.gov/hydrogenandfuelcells/fuelcells/pdfs/component_durability profile.pdf, p4. Accessed October 30, 2015.

27. Iiyama A, Iguchi S, Daimaru A, Shinohara K. Objectives, R\&D challenge topics and proposed evaluation methods for polymer electrolyte fuel cells. 2007. Fuel Cell Commercialization Conference of Japan.

28. Iiyama A, Shinohara K, Ohma A, Yoshida T, Daimaru A. Objectives, R\&D challenge topics and proposed evaluation methods for polymer electrolyte fuel cells. 2011. Fuel Cell Commercialization Conference of Japan.

29. Ohma A, Shinohara K, Iiyama A, Yoshida T, Daimaru A. Membrane and catalyst performance targets for automotive fuel cells by FCCJ membrane, catalyst, MEA WG. ECS Trans 2011; 41: 775-84.

30. Hashimasa Y, Matsuda Y, Shimizu T. Comparison of carbon corrosion test methods for polymer electrolyte fuel cell. Electrochim Acta 2015; 179: 119-25.

31. Reiser CA, Bregolia L, Patterson TW, Yi JS, Yang JD, Perry ML, Jarvi TD. A reversecurrent decay mechanism for fuel cells. Electrochem Solid St 2005; 8: A273-6.

32. Patterson TW, Darling RM. Damage to the cathode catalyst of a PEM fuel cell caused by localized fuel starvation. Electrochem Solid St 2006; 9: A183-5.

33. Park YC, Kakinuma K, Uchida M, Tryk DA, Kamino T, Uchida H, Watanabe M. Investigation of the corrosion of carbon supports in polymer electrolyte fuel cells using simulated start-up/shutdown cycling. Electrochim Acta 2013; 91: 195-207.

34. Sugawara Y, Okayasu T, Yadav AP, Nishikata A, Tsuru T. Dissolution mechanism of platinum in sulfuric acid solution. J Electrochem Soc 2012; 159: F779-86. 
35. U.S. DRIVE. Fuel cell technical team roadmap. June 2013. http://energy.gov/sites/prod/files/2014/02/f8/fctt_roadmap june2013.pdf, p8. Accessed October 30, 2015.

36. Mukundan R. Accelerated testing validation. June 2014. http://www.hydrogen.energy.gov/pdfs/review14/fc016_mukundan_2014_o.pdf, p. 11. Accessed October 30, 2015.

37. Kim T, Xie T, Jung W, Gadala-Maria F, Ganesan P, Popov BN. Development of catalytically active and highly stable catalyst supports for polymer electrolyte membrane fuel cells. J Power Sources 2015; 273: 761-74.

38. Hyeon TH, Han SJ, Sung YE, Park KW, Kim YW. High-performance direct methanol fuel cell electrodes using solid-phase-synthesized carbon nanocoils. Angew Chem Int Ed $2003 ; 42: 4352-6$.

39. Zhu YA, Sui ZJ, Zhao TJ, Dai YC, Cheng ZM, Yuan WK. Modeling of fishbone-type carbon nanofibers: a theoretical study. Carbon 2005; 43: 1694-9.

40. Sethuraman VA, Weidner JW, Haug AT, Pemberton M, Protsailo LV. Importance of catalyst stability vis-à-vis hydrogen peroxide formation rates in PEM fuel cell electrodes. Electrochim Acta 2009; 54: 5571-82.

41. Siroma Z, Fujiwara N, Ioroi T, Yamazaki S, Yasuda K, Miyazaki Y. Dissolution of Nafion ${ }^{\circledR}$ membrane and recast Nafion ${ }^{\circledR}$ film in mixtures of methanol and water. J Power Sources 2004; 126: 41-5.

42. Subramanian NP, Kumaraguru SP, Colon-Mercado HR, Kim H, Popov BN, Black T, Chen DA. Studies on Co-based catalysts supported on modified carbon substrates for PEMFC cathodes. J Power Sources 2006; 157: 56-63. 
43. Eastwood BJ, Christensen PA, Armstrong RD, Bates NR. Electrochemical oxidation of a carbon black loaded polymer electrode in aqueous electrolytes. J Solid State Electrochem 1999; 3: 179-86.

44. He C, Desai S, Brown G, Bollepalli S. PEM fuel cell catalysts: Cost, performance, and durability. Electrochem Soc Interface 2005; 14: 41-4.

45. Debe MK, Schmoeckel AK, Hendricks SM, Vernstrom GD, Haugen GM, Atanasoski RT. Durability aspects of nanostructured thin film catalysts for PEM fuel cells. ECS Trans 2006; 1: 51-66.

46. Oh HS, Oh JG, Haam S, Arunabha K, Roh B, Hwang I, Kim H. On-line mass spectrometry study of carbon corrosion in polymer electrolyte membrane fuel cells. Electrochem Commun 2008; 10: 1048-51. 


\section{List of Figures}

Figure 1. Thermal stability results at $600{ }^{\circ} \mathrm{C}$ for $1 \mathrm{~h}$ of Ketjenblack EC-300J, Vulcan XC-72, Ensaco 290G, ACCS, and carbon nanofibers.

Figure 2. Comparison of TGA profiles for Ketjenblack EC-300J, Ensaco 290G, and ACCS.

Figure 3. Comparison of XRD patterns for Ketjenblack EC-300J, Ensaco 290G, and ACCS.

Figure 4. Comparison XRD patterns for commercial Pt/C, Pt/290G, and Pt/ACCS.

Figure 5. HRTEM images and Pt particle size distributions of (a) commercial Pt/C, (b) Pt/290G, and (c) Pt/ACCS. The scale bar is $20 \mathrm{~nm}$.

Figure 6. $\mathrm{H}_{2}$-air PEMFC polarization curves of (a) commercial Pt/C, (b) $\mathrm{Pt} / 290 \mathrm{G}$, and (c) Pt/ACCS cathode catalysts before and after the support stability test (1.0-1.5 V potential cycling for 5000 cycles). The $\mathrm{H}_{2}$-air polarization performances were measured under $\mathrm{H}_{2} /$ air ( $2 / 2$ stoic.), $80{ }^{\circ} \mathrm{C}, 40 \% \mathrm{RH}$, and $170 \mathrm{kPa}$ abs.

Figure 7. Mass activities under the $\mathrm{H}_{2}-\mathrm{O}_{2}$ condition of (a) commercial Pt/C, (b) $\mathrm{Pt} / 290 \mathrm{G}$, and (c) Pt/ACCS cathode catalysts before and after the support stability test (1.0-1.5 V potential cycling for 5000 cycles). The mass activities were measured at $0.9 \mathrm{~V}_{\text {iR-corr }}$ under $\mathrm{H}_{2} / \mathrm{O}_{2}$ (2.0/9.5 stoic.), $80{ }^{\circ} \mathrm{C}, 100 \% \mathrm{RH}$, and $150 \mathrm{kPa} \mathrm{abs}_{\text {ab. }}$

Figure 8. EIS plots under the $\mathrm{H}_{2}$-air condition of (a) commercial Pt/C, (b) $\mathrm{Pt} / 290 \mathrm{G}$, and (c) Pt/ACCS cathode catalysts before and after the support stability test (1.0-1.5 V potential cycling for 5000 cycles).

Figure 9. Dispersion of Ketjenblack EC-300J, Ensaco 290G, and ACCS in water/hexane mixture. Figure 10. Contact angle measurements on (a) Ketjenblack EC-300J, (b) Ensaco 290G, and (c) ACCS. 


\section{List of Tables}

Table 1. List of carbons and carbon properties.

Table 2. Comparison of maximum power density and mass activity changes after stability test for commercial Pt/C, Pt/290G, and Pt/ACCS catalysts. 


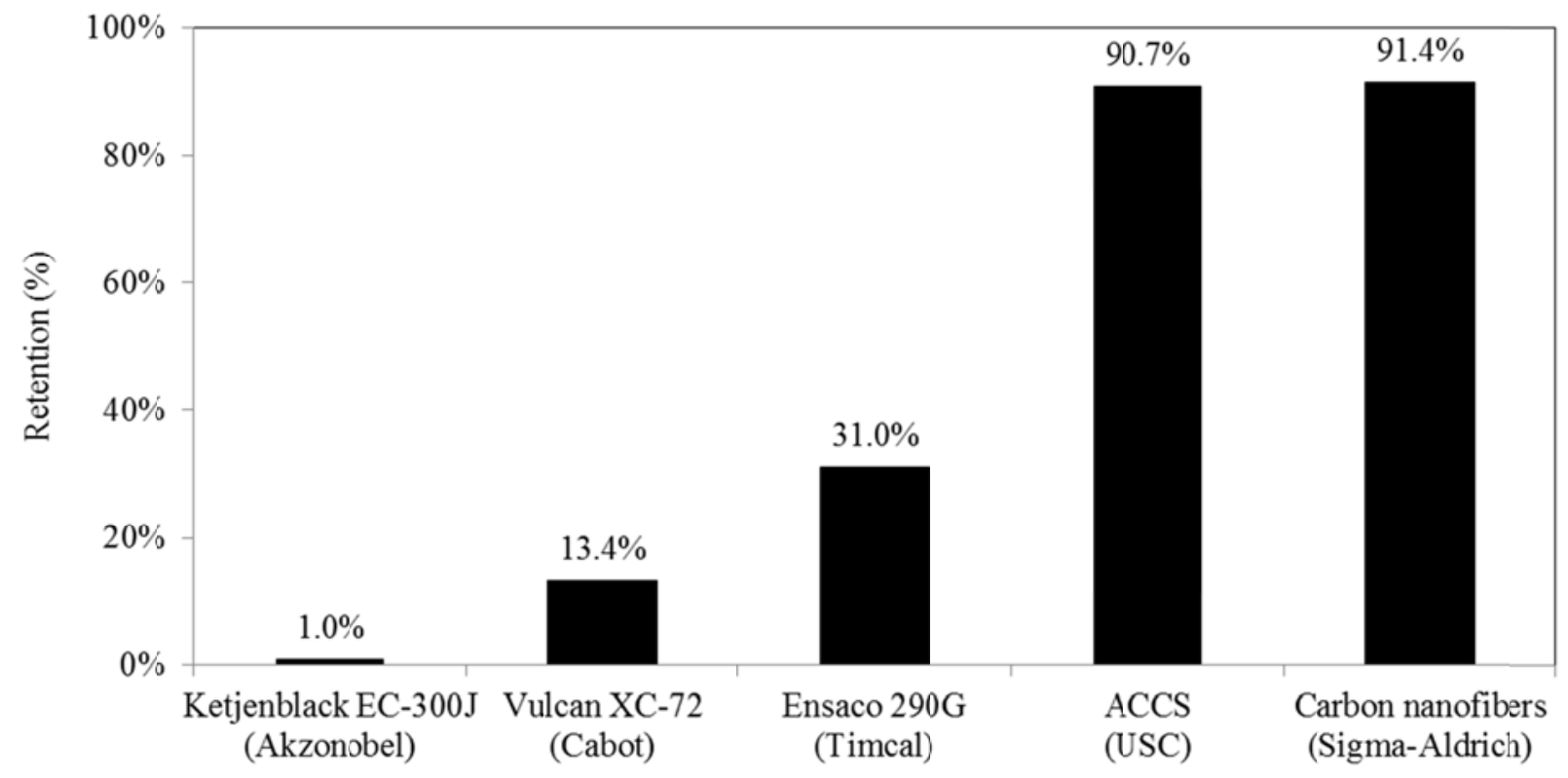

Fig. 1

Kim et al. 


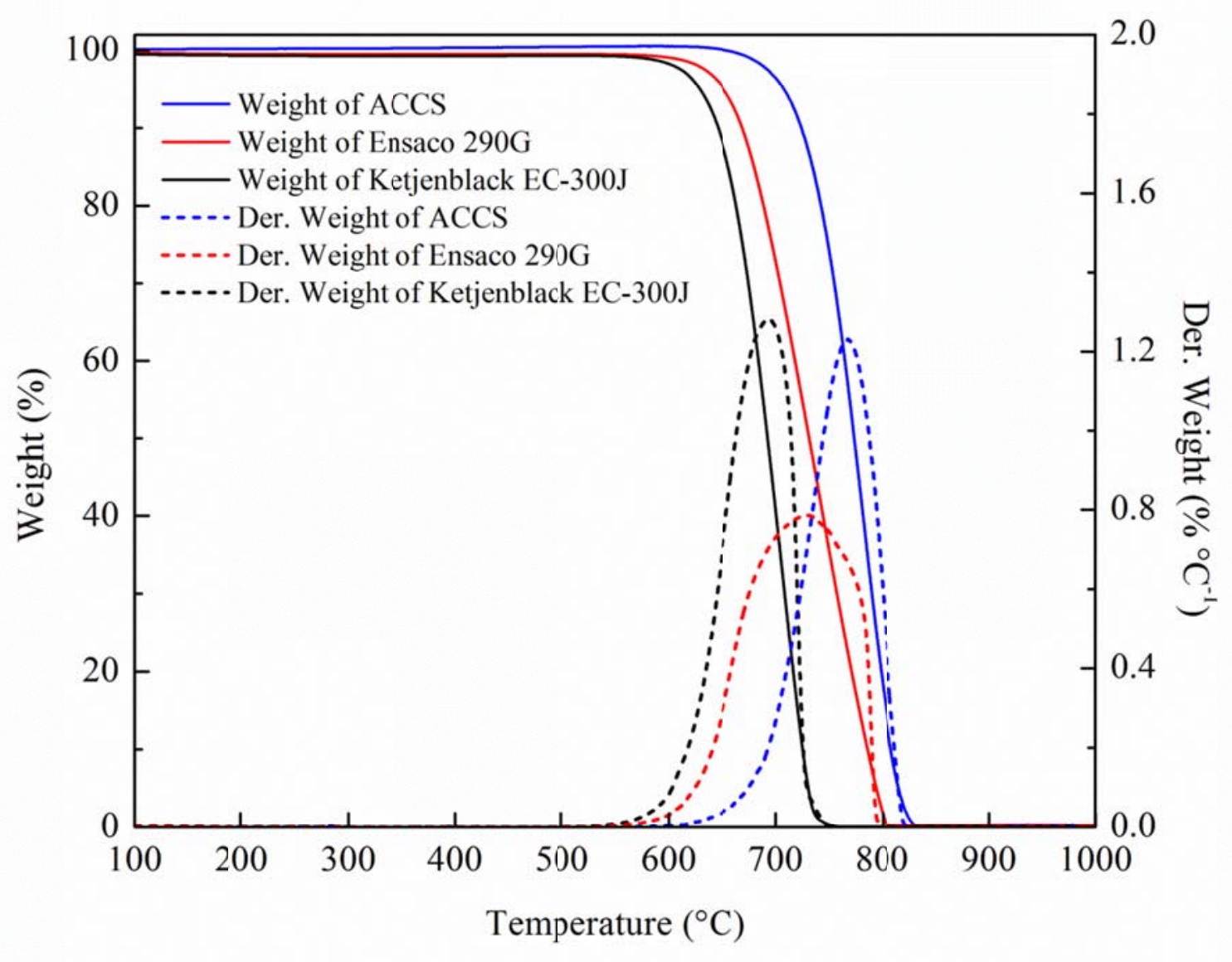

Fig. 2

Kim et al. 


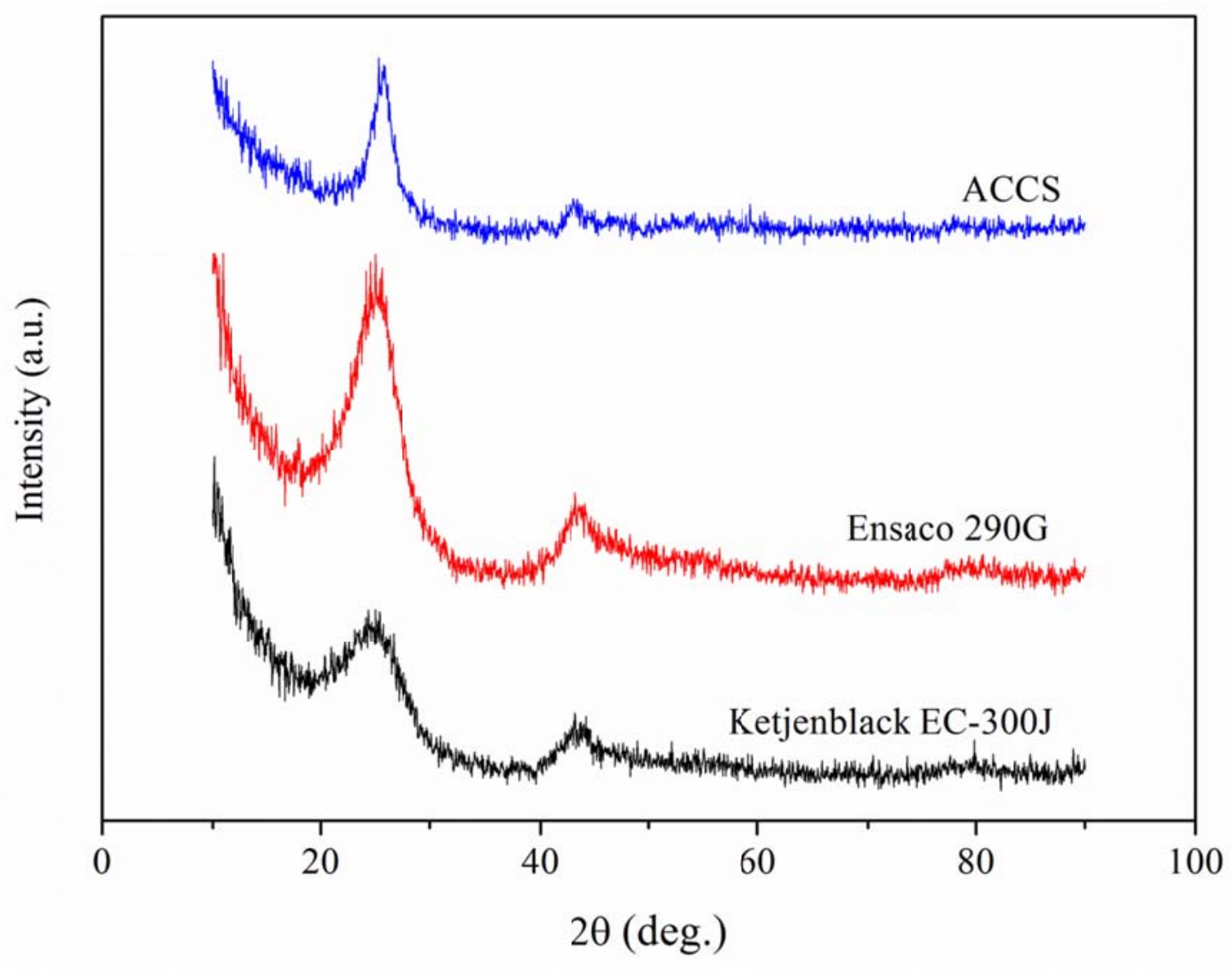

Fig. 3

Kim et al. 


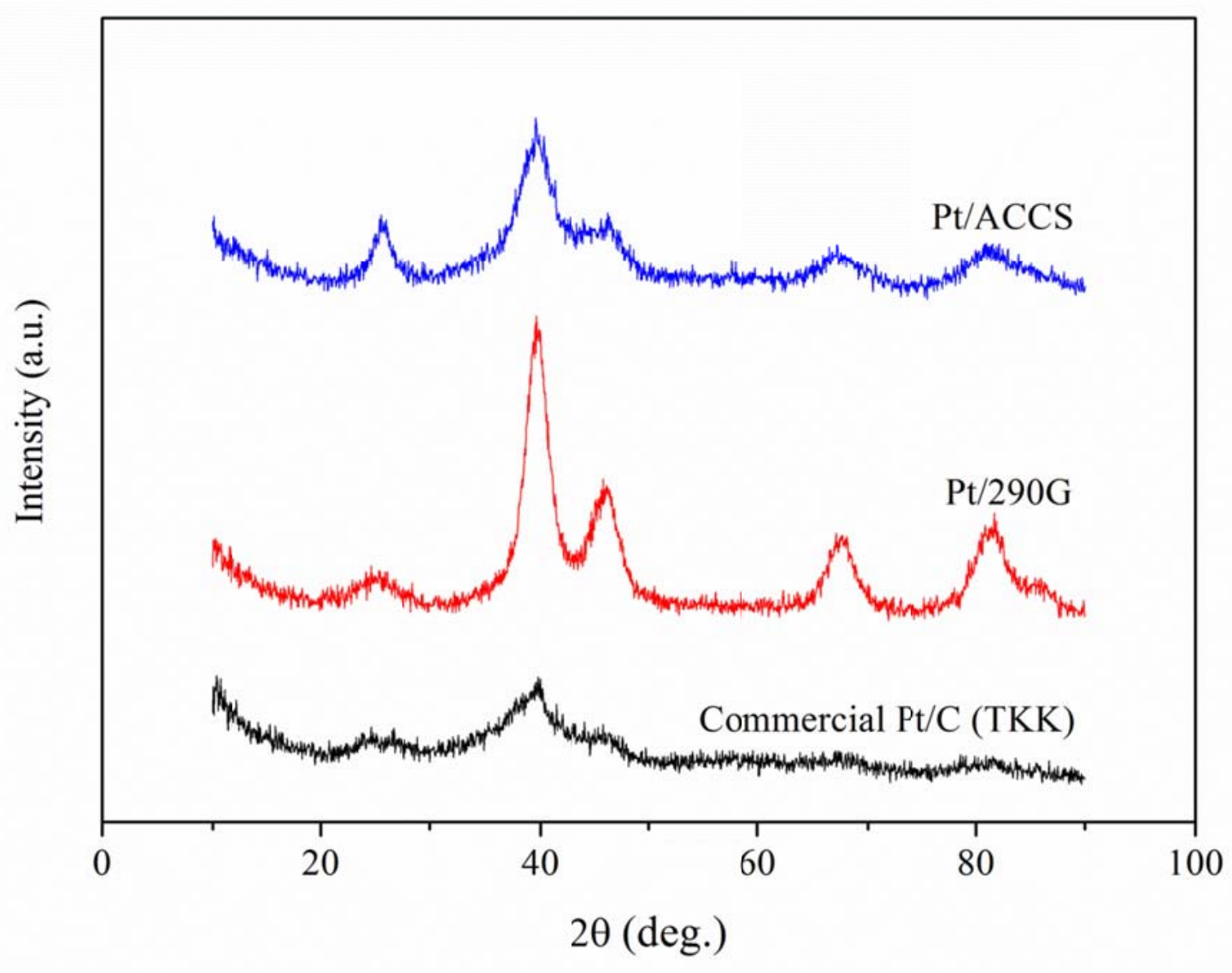

Fig. 4

Kim et al. 

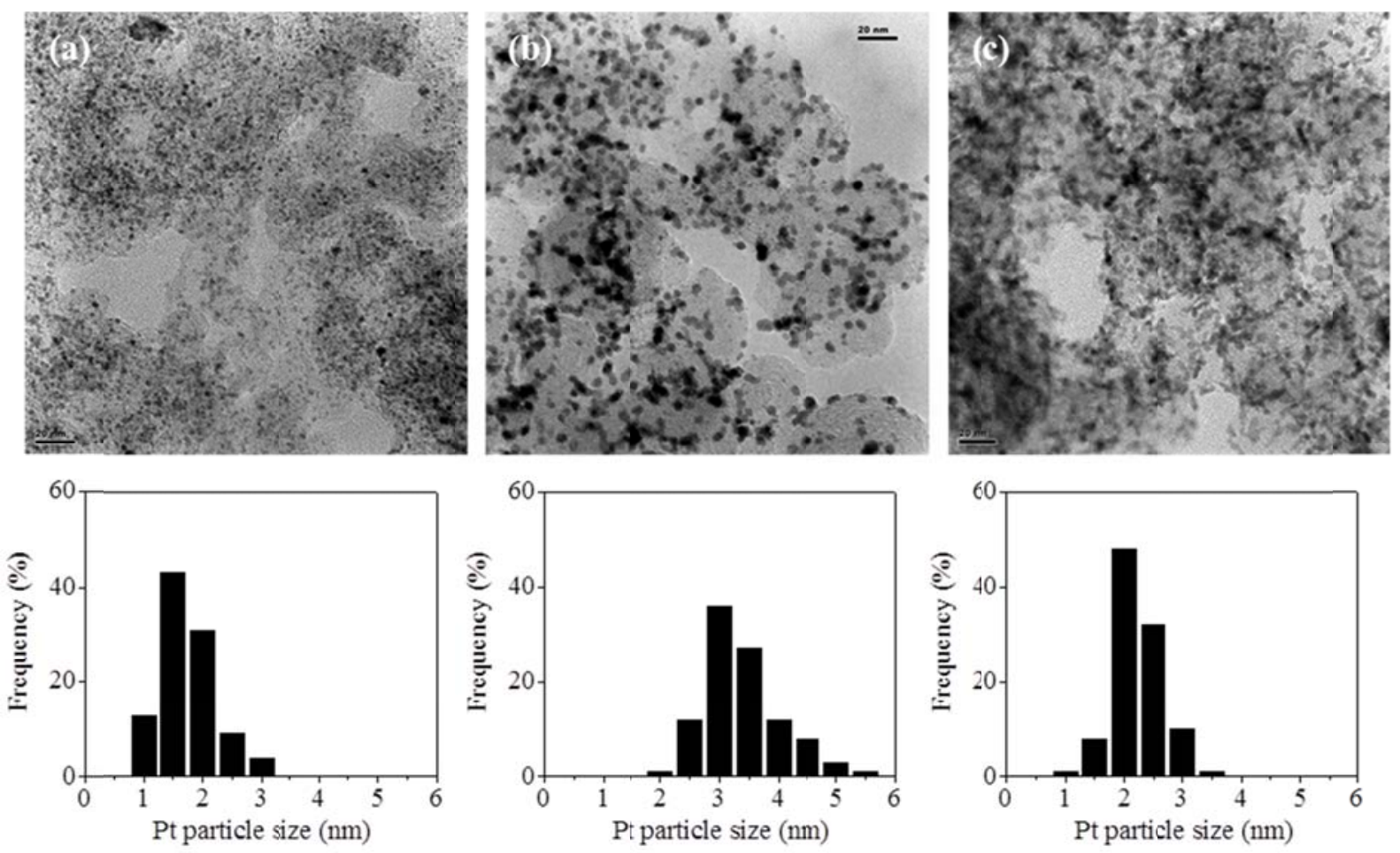

Fig. 5

Kim et al. 

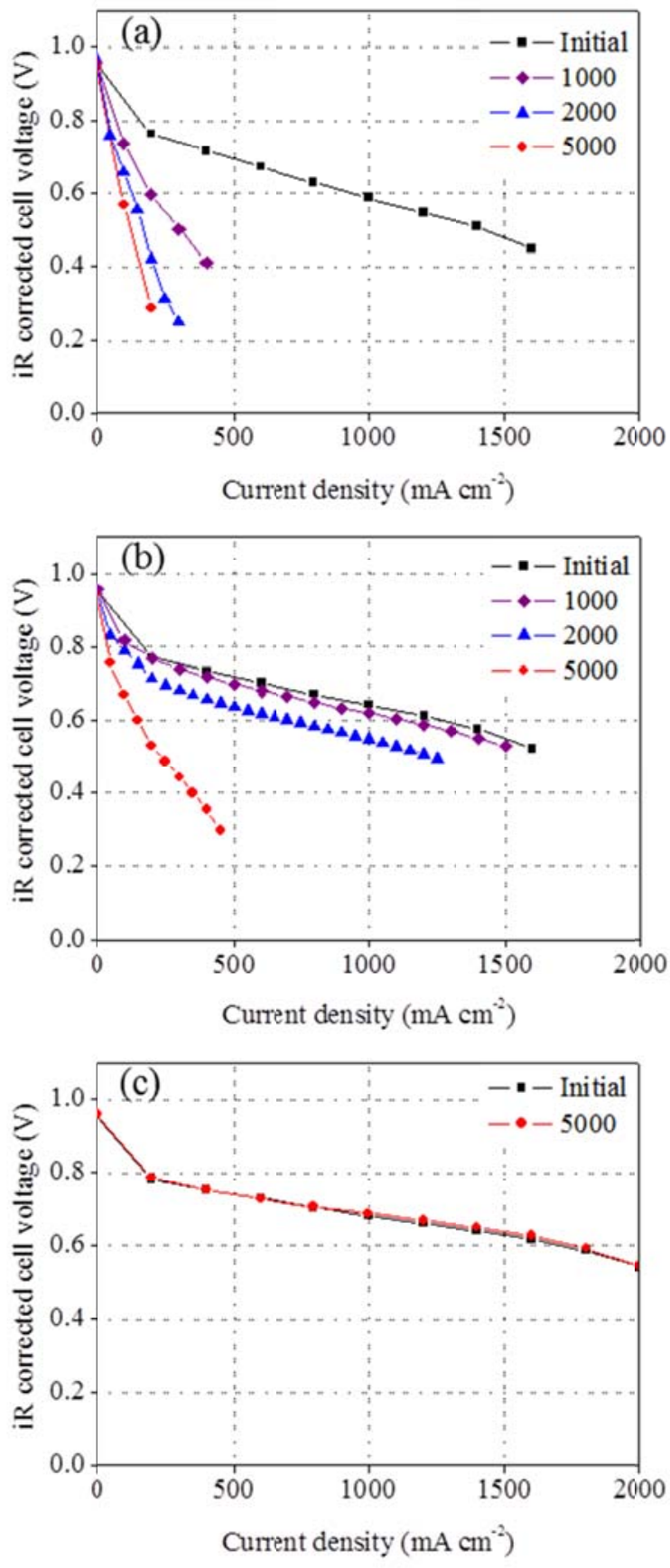

Fig. 6

Kim et al. 

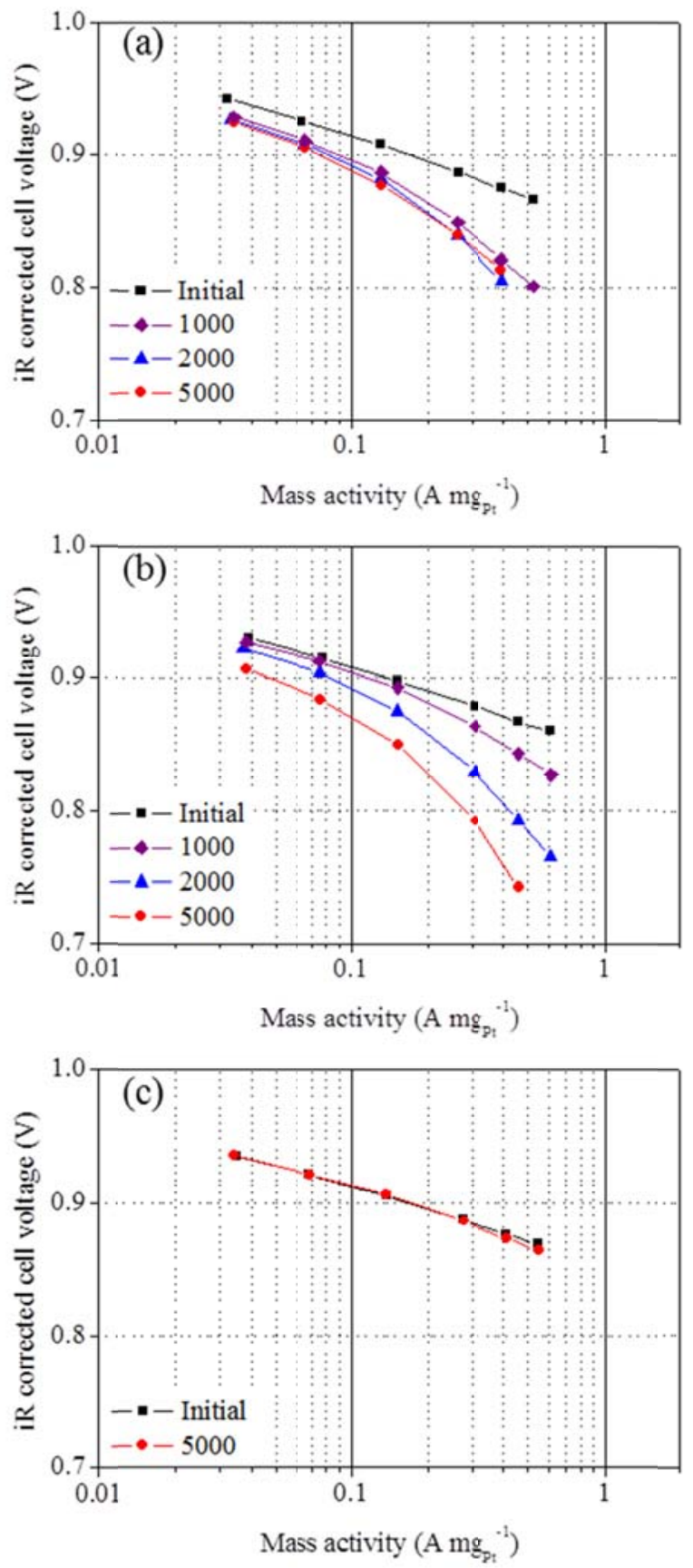

Fig. 7

Kim et al. 

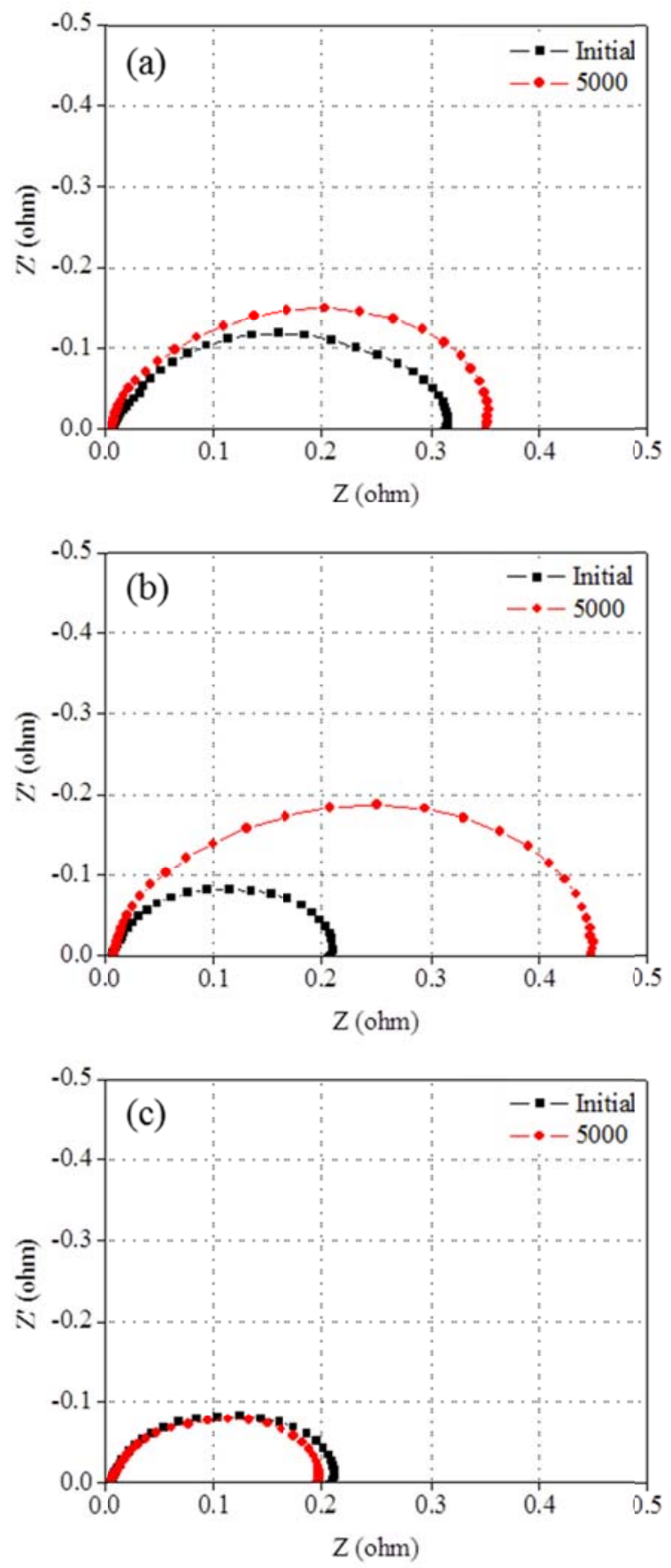

Fig. 8

Kim et al. 


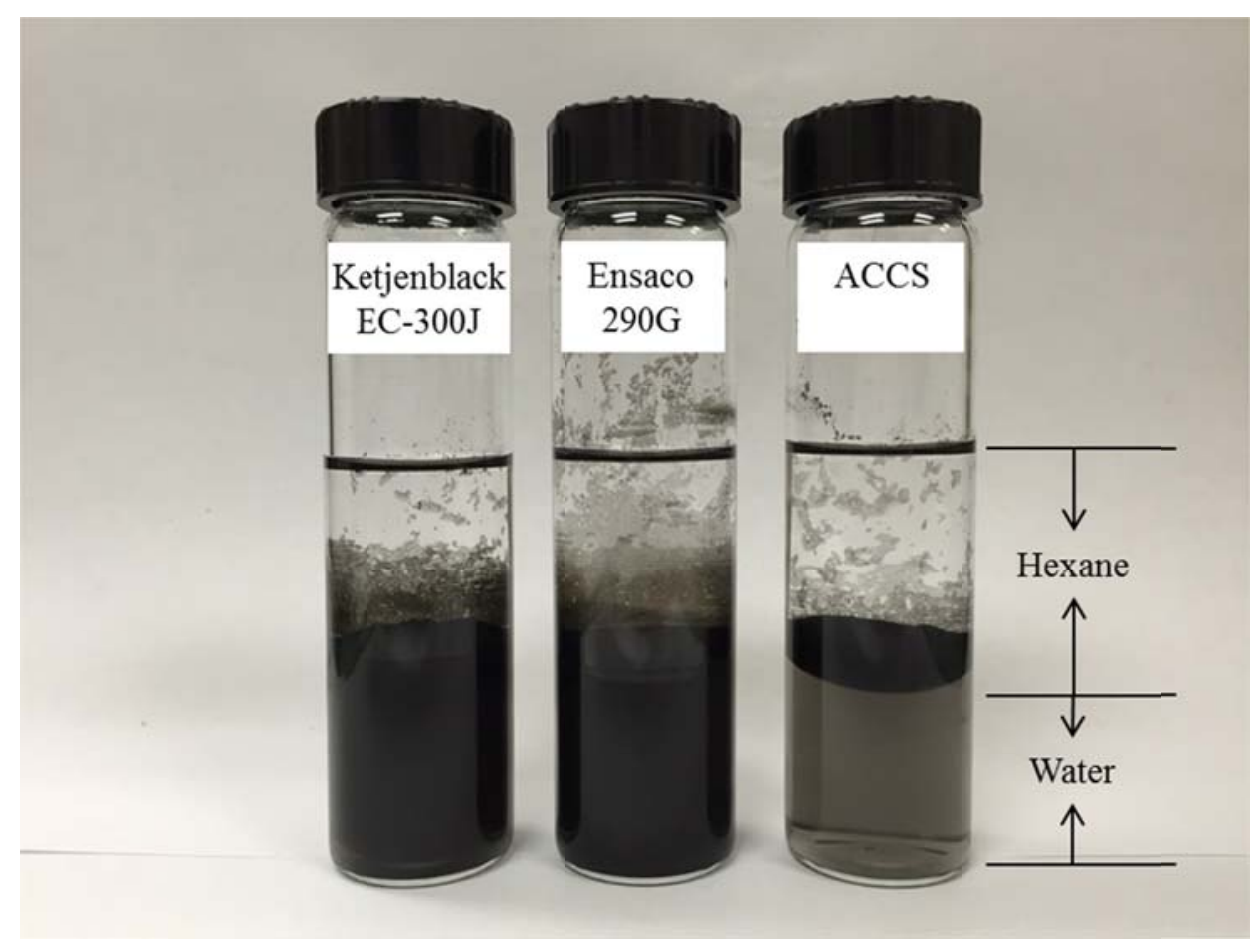

Fig. 9

Kim et al. 

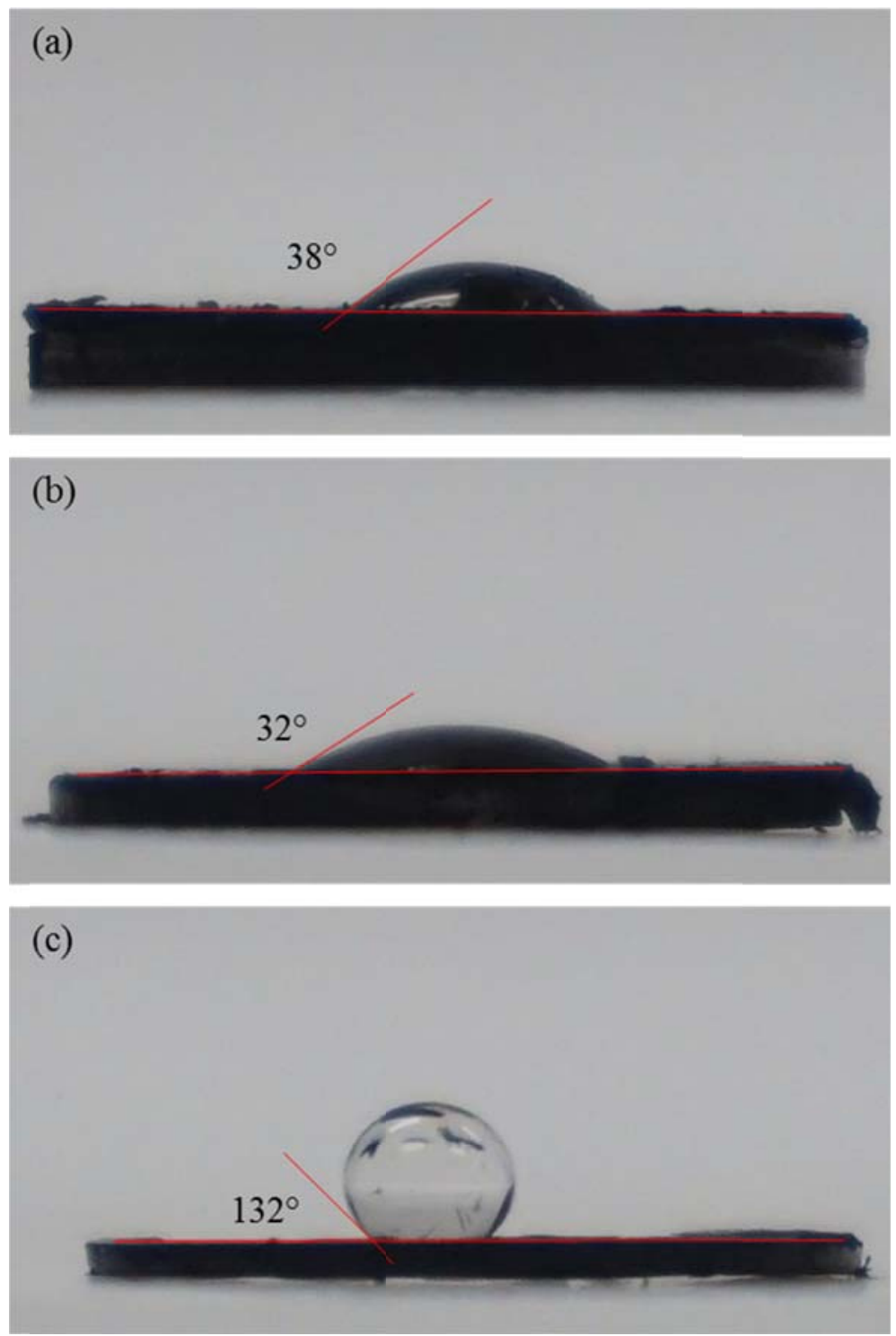

Fig. 10

Kim et al. 
Table 1. List of carbons and carbon properties.

\begin{tabular}{ccccc}
\hline Sample & $\begin{array}{c}\text { Surface area }\left(\mathrm{m}^{2} \mathrm{~g}^{-1}\right) \\
(\mathrm{BET})\end{array}$ & $\begin{array}{c}\mathrm{L}_{\mathrm{c}}(\mathrm{nm}) \\
(\mathrm{XRD})\end{array}$ & $\begin{array}{c}\mathrm{d}_{002}(\mathrm{~nm}) \\
(\mathrm{XRD})\end{array}$ & $\begin{array}{c}\text { Max der. temp. }\left({ }^{\circ} \mathrm{C}\right) \\
(\mathrm{TGA})\end{array}$ \\
\hline $\begin{array}{c}\text { Ketjenblack } \\
\text { EC-300J }\end{array}$ & 800 & 1.8 & 0.361 & 705 \\
Ensaco 290G & 220 & 2.0 & 0.358 & 740 \\
ACCS & 200 & 4.0 & 0.349 & 781 \\
\hline
\end{tabular}


Table 2. Comparison of maximum power density and mass activity changes after stability test for commercial Pt/C, Pt/290G, and Pt/ACCS catalysts.

\begin{tabular}{|c|c|c|c|c|c|c|}
\hline \multirow{2}{*}{ Sample } & \multicolumn{3}{|c|}{ Maximum power density $\left(\mathrm{mW} \mathrm{cm}{ }^{-2}\right)$} & \multicolumn{3}{|c|}{ Mass activity $\left(\mathrm{A} \mathrm{mg}{ }_{\mathrm{Pt}}^{-1}\right)$} \\
\hline & Initial & $\begin{array}{c}\text { After } 5000 \\
\text { cycles }\end{array}$ & $\begin{array}{c}\text { Change } \\
(\%)\end{array}$ & Initial & $\begin{array}{c}\text { After } 5000 \\
\text { cycles }\end{array}$ & $\begin{array}{c}\text { Change } \\
(\%)\end{array}$ \\
\hline Commercial Pt/C & 495 & 56 & -88.7 & 0.167 & 0.071 & -57.5 \\
\hline $\mathrm{Pt} / 290 \mathrm{G}$ & 530 & 85 & -84.0 & 0.139 & 0.047 & -66.2 \\
\hline $\mathrm{Pt} / \mathrm{ACCS}$ & 722 & 793 & 9.8 & 0.165 & 0.167 & 1.0 \\
\hline
\end{tabular}

